\title{
The Study on the International Production Capacity Cooperation of the China - Indochina Peninsula Economic Corridor
}

\author{
Li Zhu \\ Research Institute for the Indian Ocean Economies \\ Yunnan University of Finance \& Economics \\ Kunming, China \\ zhuli2001@126.com
}

\author{
Jingyi Zhu* \\ School of International Languages and Culture \\ Yunnan University of Finance \& Economics \\ Kunming, China \\ 526934738@qq.com
}

\begin{abstract}
This article presents a new exploration of the international production capacity cooperation of the China Indochina Peninsula Economic Corridor. It provides backgrounds on the international production capacity cooperation for the construction of regional value chains, and analyzed the implications and basis for such cooperation as well as provided suggestions for promoting the development of the priority areas of international production capacity cooperation of the Indochina Peninsula Economic Corridor. The article concludes that the international production capacity cooperation of China - Indochina Peninsula Economic Corridor will promote the optimized distribution of production factors and industries of the various countries as well as enhance their competence.
\end{abstract}

Keywords-production; capacity; cooperation; Indochina Peninsula; China

\section{INTRODUCTION}

After the China - ASEAN (10+1) cooperation framework was set up, the economic and trade cooperation between China and the countries along the Indochina Peninsula Economic Corridor has developed increasingly closer with expanding scale of cooperation. The construction of China - Indochina Peninsula Economic Corridor will elevate the regional economic cooperation, and promote regional economic integration. The international production capacity cooperation is aimed at building regional value chains. This cooperation is based on the development of the industry and the dominant industry cultivation of the countries along the China Indochina Peninsula Economic Corridor. It will integrate the production factors and resources in this region to set up a production network with coordinated development of all industries and to achieve complementary and win-win development of the industries in this region. Against the background of the huge Chinese market and the China's transferring of the manufacturing industry advantage, the international production capacity cooperation of China Indochina Peninsula Economic Corridor will promote the optimized distribution of production factors and industries of the various countries as well as enhance their competence.

\footnotetext{
* Corresponding author
}

\section{THE INTERNATIONAL PRODUCTION CAPACITY COOPERATION FOR THE CONSTRUCTION OF REGIONAL VALUE CHAINS}

The basis for international capacity production is the specialization of industry and international division of labor. Arndt pointed out that the preferential trade agreements between countries eliminated certain trade barriers and reduced the transaction costs, which further promotes the development of international division of labor and international trade. A study by $\mathrm{Ke}-\mathrm{Mu} \mathrm{Yi}[1]$ indicated that the division of labor in the Global Value Chain (GVC) contributed to nearly $70 \%$ of the international trade growth. However, the lowering of the international transport and communication costs brought out by economic development and technology advancement is the main reason for the rapid development of the international division and labor and intermediate products trade. Gereffi proposed a global commodity chain analysis framework [2-4]. $\mathrm{He}$ also proposed a binary driving mode of the global commodity chains, i.e. the producer-driven mode and the buyer driven mode. He believed that the division, restructuring as well as the normal functioning of the various links in the global value chains were driven by producers or buyers. The producer-driven mode means the producers make investment to promote market demand, which forms the vertical system of division of labor in the global production and supply chain.

With the rapid development of the emerging economies represented by China, the participation of the emerging economies and Asian countries in the global value chains has become the focus of attention for many scholars. Since 1990s', the developing economies of Asia (China and ASEAN) have been further integrated into the East Asian production network value chain. In the future, more developing countries in Asia will be integrated into this value chain [1]. As a matter of fact, the industry development policies oriented toward the global value chain in the emerging economies and the emerging market economies have brought about remarkable benefits for the suppliers, the specialized development of the global value chain as well as emerging economies [3-5]. The opening-up and development of China's economy also enhanced the scale and extent of the participation of Chinese enterprises into the global value chain [6-7]. The characteristics of the industries 
will cause positive and negative effect on and adjustment to the internationalization process of the industries [8]. The integration of production capacity and regional value chain and network reconstruction must be taken into consideration when promoting the production capacity cooperation of the Indochina Peninsula Economic Corridor.

In December 2014, Premier Li Keqiang proposed for the first time the initiative of building the new mode of Sinoforeign cooperation by "production capacity cooperation" during his visit to Kazakhstan. In April 2015, Premier Li Keqiang hosted the Forum on China's Equipment Manufacturing Going Out to Overseas Markets and Promotion of International Production Capacity Cooperation during which he pointed out that accelerating the overseas sales of Chinese equipment and promoting the international production capacity cooperation are important measures to improve the quality and efficiency of the Chinese economy. They will be beneficial to form the new advantages of an open economy scheme with high quality import and export, which will promote further integration of Chinese economy and the world economy. The production capacity cooperation refers to the coordinated action between two countries or regions with both intention and demand to distribute their production capacity transnationally or trans-regionally [9]. In May 2015, NDRC, with other ministries, promulgated the "Guiding Opinions of the State Council on Promoting International Cooperation in Industrial Capacity and Equipment Manufacturing”. This document proposed the general task that China will focus on those developing countries with high compatibility in equipment and production capacity with China, strong intention for cooperation as well as good cooperation condition and basis. It also pointed out that China will progressive expand to the markets in developed countries with trial spots first. This document has analyzed 12 key industries.

When analyzing international production cooperation, we need to first clarify the relation between the two concepts of overcapacity and industry transfer. First, as a new mode for overseas cooperation, the production capacity cooperation implies the premise of overcapacity of the Chinese industries. And the overcapacity is the main dilemma that the economic transformation and development of China is faced with now. The overcapacity of China does not refer to low quality capacity or backward capacity. If we take a look at the 12 key industries listed in the Guiding Opinions, we will find both the basic industries of steel and non-ferrous metal as well as hightech industries of railway, telecommunication and aviation. These industries have accumulated much advantage over many years of development and have had strong competence internationally. We must understand that the international capacity cooperation is not only the export of the backward capacity of China. Second, the production capacity cooperation contains industry transfer, but it does not totally equate with industry transfer. On the one hand, the production capacity cooperation emphasizes building a new international economic cooperation mode, including government to government cooperation, while industry transfer is mainly an organizational behavior. On the other hand, the international production capacity cooperation is conducted based on equality, mutual benefits and win-win situation. It is an economic and technological cooperation based on the industry development need of both countries. Industry transfer is only one-way action, but production capacity cooperation can be two-way action.

The international production capacity cooperation is a mutually dependent and mutually enhancing process. This cooperation is proposed by China, and must be matched with the development plan and need of the target countries to seek common grounds in the areas of production capacity cooperation so as to achieve the coordinated and win-win development of industries. The international production capacity cooperation is a further development based on the existing economic cooperation. Therefore we need to conduct scientific analysis and research on the industry features, the extent of the industry openness, as well as the influence of the industries of multiple countries in the region of Indochina Peninsula Economic Corridor to define the areas of cooperation to achieve mutual benefits and win-win development.

\section{THE IMPLICATION AND BASIS OF THE INTERNATIONAL PRODUCTION CAPACITY COOPERATION IN THE INDOCHINA ECONOMIC CORRIDOR}

\section{A. The implication of the international production capacity cooperation in the Indochina Economic Corridor}

China - Indochina Peninsula Economic Corridor is one of the six economic corridors planned in the "Belt and Road" initiative. It includes the six countries of Laos, Vietnam, Cambodia, Thailand, Malaysia and Singapore. This is a region with great development potential but also with most imbalanced economic development. Accelerating the international production capacity cooperation in the Indochina Economic Corridor will upgrade the trade cooperation level of this region, as well as enhance the momentum and dynamics of economic development of the countries in this region.

First, the international production capacity cooperation will inject new impetus to the development of this region. China and ASEAN has long established close trade cooperation relation. ASEAN is the third largest trading partner of China. In 2014, the total volume of import and export trade between China and ASEAN was USD 480.125 billion. In 2015, the bilateral trade volume was USD 472 billion. At the end of 2015 , the bilateral investment reached USD 150 billion. The increasing trade and investment cooperation provides good basis for international production capacity cooperation. At the same time, the promotion of production capacity cooperation will inject new impetus to the industry cooperation and development of this region.

Second, the international production capacity cooperation will promote the complementary development of the industry advantages of the countries along the Economic Corridor as well as the coordinated development of the industries in the region. The production capacity cooperation is based on the development basis and advantages of the industries of these countries. It fully exerts the potential and advantages of these industries, enables distribution of industries and sharing of resources in this region to form a development framework with complementary development of the industry advantages and to promote the coordination effect of the industries in the region. 
Third, the international production capacity cooperation will promote the construction of the regional value chain and enhance the industrial competence of the countries in the region. Against the background of the globalization of world economy, the global distribution of the industrial resources has become an inevitable development trend of the globalization of economy. It has been the priority of the economic development strategy of different countries to rapidly integrate into the global industrial chain and to promote the development of industries based on the construction of the global value chains. The production capability cooperation will fully exerts China' s advantage in industry, capital, technology and market which have achieved great development since the reform and opening up. Through multi-level and multi-mode international production capability cooperation, we will be able to promote the in-depth integration of the industries of the partner countries, join hands in building the regional value chains, upgrade the industrial competence of all countries, and accelerate the sustainable and rapid development of the different countries.

\section{B. The basis for the international production capacity cooperation of the Indochina Peninsula Economic Corridor}

Over time, China and the countries along the Indochina Peninsula Economic Corridor has established close and stable political and economic ties, which provides a solid foundation for economic cooperation and development. From the perspective of the globalized development of world economy as well as the perspective of regional economic integration and multi-lateral economic cooperation, there is good basis for promoting the international production capability cooperation between China and the countries along the Indochina Peninsula Economic Corridor.

\section{1) A complete and multi-level regional cooperation} mechanism has been set up.

Currently, China has set up a multi-level regional cooperation mechanism with the countries in Indochina Peninsula and ASEAN. In 1992, the creation of the GMS promoted the cooperation and development of the economy of this region after over 20 years of continued effort. In 2001, China-ASEAN FTA was established, which sped up the fullscale economic cooperation between China and ASEAN. The RCEP (Regional Comprehensive Economic Partnership) initiated by ASEAN and participated by China has also been progressing. In 2015, the Lancang-Mekong Cooperation (LMC) mechanism was accomplished, which is a closer cooperation mechanism for promoting the regional cooperation and development. The establishment of a series of regional cooperation mechanism provides institutional warrant for the production capacity cooperation for the countries along the economic corridor.

\section{2) Forming of the regional connectivity network}

After years of efforts, the three-dimensional connectivity network between China and Indochina Peninsula has finished construction. For land connection, Kunming - Hanoi Highway, Kunming - Bangkok Highway and China-Myanmar Highway have been put into use. For air routes, Kunming and Nanning of China have started direct flights to the main cities of the countries in Indochina Peninsula. For water transport, the second phase of construction for the Lancang-Makong channel has started and the land and water transport between China and Myanmar, Laos and Vietnam is also making rapid progress. For railways, the section of Dian-Vietnam railway within the territory of China has completed its upgrading. The Sino-Lao railway construction is also speeding up and is expected to be put into use in 2020. The three-dimensional connectivity network promotes the in-depth cooperation of the regional economy and provides fundamental transport guarantee for the production capacity cooperation of the Economic Corridor.

Admittedly, the connectivity is not in itself a goal but a measure. Accomplishing the "hard" connectivity does not mean the completion of the construction of the Economic Corridor. The core of the Economic Corridor construction is the integration and coordination of the regional economy. Therefore, promoting the production capacity cooperation between China and the countries along the Indochina Peninsula Economic Corridor is an important direction for promoting and upgrading "Belt and Road" as well as the regional connectivity.

3) Huge space for production capacity cooperation with the rapid growth of the economy of the countries along the Economic Corridor.

In recent years, the countries along the Economic Corridor have maintained a good development trend. Especially, Laos, Myanmar and Vietnam's economy grow rapidly. The average growth rate for the economy in ASEAN countries is over $5 \%$. Based on the statistics of World Bank, during 2011-2015, the average growth rate of GDP in Laos reached $7.4 \%$, and the per capita GDP jumped from USD 319 to USD 1,970. In 2014, the GDP growth rate of Vietnam was $6 \% ; 6 \%$ for Malaysia; and Myanmar had the greatest GDP growth rate, 7.7\%. The rapid growth of the economy in these countries not only transformed the domestic development environment, but also provides better condition for deepening regional economic cooperation.

4) China's industries are complementary with that of the countries along the Economic Corridor.

Over the 30 years of reform an opening-up, China has formed a complete industrial structure, with many industries becoming highly competitive internationally, including steel, non-ferrous metals, building materials, railway, electric power, chemical engineering and mechanical manufacturing. China has also accumulated rich experience and high technology in industrial development. Some countries along the Economic Corridor, including Laos, Myanmar, and Cambodia are agricultural countries with backward economic development. These countries lack a systematic industrial structure and have great demand for industrial development. Countries like Singapore, Thailand, Vietnam and Malaysia are more developed in their economy but the product structure is still quite simple. The underdevelopment of the industry and the difference in the development levels of the countries along the Indochina Peninsula provides great space for international production capacity cooperation. The promotion of the international production capacity cooperation of the Economic Corridor will be conducive to achieving the complementary development of the industry advantages between China and the countries in the region. 


\section{Promoting the DeVElopMent of the Priority AREAS OF INTERNATIONAL PRODUCTION CAPACITY COOPERATION OF THE INDOCHINA PENINSULA ECONOMIC CORRIDOR}

\section{A. The route of the international production capacity cooperation of the Indochina Peninsula Economic Corridor}

The international production capacity cooperation proposed by Chinese government is to integrate the industry advantage and capital advantage of our country with the overseas demand. China will greatly promote the market-oriented and enterpriseled international production capacity and equipment manufacturing cooperation.

The international production capacity cooperation will not only promote the domestic economic development as well as industry upgrade and transformation, but will also expand the space for regional economic cooperation and create the new mode of Sino-foreign cooperation.

The international production capacity cooperation should be developed based on the principles of mutual benefits, mutually complementary and coordinated development. The industries which are of concern to both parties of the cooperation, have strong trick-down effect on the economic development of the countries, and promote the coordinated development of the region should be prioritized. The production capacity cooperation will cultivate the mainstream and advantaged industries of each country, improve the competence of industries, construct regional value chains and form regional production network structure. It will also promote the free and proper flow of the regional production factors to enable the complementary development of the advantages in resources, technology, capital and market.

The production capacity cooperation is not only one-way industry export, but also focuses on improving the industry performance of the target countries. The industry structure, industry development orientation and the industries of each country may be connected and integrated to form the selection of industries for cooperation. With the integration of industry coordination and production factors, we may improve the industry structure and enhance the industry competence of all the countries.

\section{B. The key areas for the promotion of the international production capacity cooperation of the Indochina Peninsula Economic Corridor}

1) Strengthening the connectivity and infrastructure construction of the Economic Corridor

Connectivity is an important basis for deepening regional cooperation. Although the connectivity network between China and this region has been set up, the transport network leaves much to be upgraded. For example, there is no high-level international highway between China-Myanmar and ChinaLaos. At the same time, there still needs adequate logistic and transport facilities. High quality and complete connectivity facilities are the basic guarantee for production capacity cooperation. Therefore, the countries along the Economic Corridor should reach consensus to strengthen the transport network between the countries in the region as well as to accelerate the construction of the domestic transport network so as to provide efficient and convenient transport network for strengthening regional economic cooperation.

China will need to speed up the construction projects of Sino-Laos, Sino-Thailand railway and Sino-Myanmar land and water transport route. We must continue to improve and upgrade the infrastructure along the Indochina Peninsula and greatly reduce the transaction costs for regional economic cooperation to expand the market space.

2) The key areas for international production capacity cooperation

First, we must accelerate the establishment of the production capacity cooperation platforms.

The international production capacity cooperation of the Economic Corridor should focus on the cooperation of the industry competence to set up systematic industry cooperation structure. It does not simply equate with traditional international investment. For this purpose, emphasis should be put on establishing international production capacity cooperation platforms including international industrial parks, international economic cooperation areas, as well as crossborder economic cooperation areas. The establishment of such platforms will transform the simple project investment mode into a systematic regional industry cooperation framework to achieve the effect of economies of scope. Currently, China should put emphasis on the construction of Mohan - Moding Economic Cooperation Area between China and Laos; SinoVietnam Cross-border Economic Cooperation Area as well as Sino-Myanmar Cross-border Economic Cooperation Area. We should also accelerate the construction of the Chinese industrial parks in the countries along the Economic Corridor. The production capacity cooperation will be set up based on the industrial parks and the in-depth integration of the industry and capacity of both countries will be systematically pushed forward.

This cooperation should be conducted through international investment, multinational companies and international trade. The governments of various countries will provide guarantee by enacting proper policies and setting up certain cooperation mechanisms.

Second, we should strengthen the cooperation of the key industries. The achievement of China's reform and opening-up is not only represented by the rapid growth of economy, but also represented by the great improvement in the technology level and international competitiveness of Chinese industries. After over 30 years of reform and opening-up, a myriad of industries in China have become lead industries in the world, e.g. steel, railway, electric power and equipment manufacturing. These industries have great advantage and high quality overcapacity. Chinese equipment and products are highly costbenefit. Therefore, the production capacity cooperation may help the countries along the Economic Corridor to upgrade their level of industrialization and commercialization.

The international production capacity cooperation must take into consideration the industry development policies and current industry basis of the countries along the Economic Corridor. With the principle of mutual benefits and win-win development, we may select the industries with complementary 
advantages which are in urgent need in each country as the key areas of cooperation to systematically promote the production capacity cooperation. Based on the fact that the basic industries are quite backward in these countries, while the resources and labor are quite abundant, we should fully exert the comparative advantage to strengthen the cooperation in infrastructure, electric power, building materials, construction machinery, telecommunication and labor-intensive industries. The regional value chains will be set up to promote the construction of the regional production network and to upgrade the connection of the regional industries so as to achieve the all-round integration of industries, capital, technology and market. system

3) Accelerating the establishment of financial supporting

Financial support is a guarantee for production capacity cooperation. It is an important pillar of upgrading the trade and investment capability of the Economic Corridor. Therefore, establishing a complete financial supporting system for the Economic Corridor is an important component of international production capacity cooperation.

First, we must push forward the platforms of AIIB and Silk Road Fund to lend support to the infrastructure construction along the Economic Corridor and to improve the investment environment and trade conditions.

Second, we have set up Lancang-Mekong Cooperation Fund. In March, 2015, in the First Summit of Lancang River Mekong River, Chinese Premier Li Keqiang announced that China will set up the preferential loans of RMB 10 billion as well as USD 10 billion credit line, including USD 5 billion preferential export credit for buyers and another USD 5 billion special-purpose loan for production capacity cooperation to support the infrastructure construction and capacity

\section{ACKNOWLEDGMENT}

The authors of this paper would like to thank the anonymous reviewers and the editor for making possible the publication of this article.

\section{REFERENCES}

[1] K.M. Yi, "Can Vertical Specialization Explain the Growth of World Trade?" Journal of Political Economy, vol. 111, 2003, pp. 52-102.

[2] Gereffi, "International trade and industrial upgrading in the apparel commodity chain," JOURNAL OF INTERNATIONAL ECONOMICS, vol. 48, pp. 37-70, June 1999.

[3] G. Gereffi, and T. Sturgeon, "Global Value Chain-Oriented Industrial Policy: The Role of Emerging Economies," Global Value Chains in a Changing World, Edited By Deborah K, Elms and Patrick Low, 2013

[4] G. Gereffi, "A Global Value Chain Perspective on Industrial Policy and Development in Emerging Markets," Duke Journal of Comparative \& International Law, vol. 24, 2014a, pp. 433-458.

[5] G. Gereffi, "Global Value Chains in a Post-Washington Consensus World," Review of International Political Economy, vol. 21, 2014b, pp. 9-37.

[6] H. Zhang, "The Motivation Mechanism of the Global Value Chain and Industry Development Strategy," China Industrial Economy, vol. 1, 2006

[7] J. Zhang, "The Formation of Global Value Chain under the Condition of Demand Competition and the Upgrading Dilemma and Breakthrough of the Competitive Advantage of Developing Countries," Economic Altitude, vol. 2, 2008.

[8] J. Zhang, S. Ge, and C. Zhou, “The Impact of Industrial Characteristics on Industrial Internationalization Process - Case of Cross-border Merger and Acquisition,” Nankai Economic Studies, 2012, pp. 3-19.

[9] M. Zhou, "Emphasis on and Precaution of the "Belt and Road" Transnational Production Capability Cooperation," China Development Observation, December 2015. 